\title{
Pelusios niger (Duméril and Bibron 1835) - West African Black Mud Turtle
}

\author{
Luca Luiselli ${ }^{1,4,5}$, Roger Bour ${ }^{2}$, Fabio Petrozzi $^{3}$, \\ Godfrey C. Akani ${ }^{4}$, and Gabriel H. Segniagbeto ${ }^{5}$ \\ ${ }^{1}$ Institute for Development, Ecology, Conservation and Cooperation, \\ via G.Tomasi di Lampedusa 33,00144 Rome, Italy [l.luiselli@ideccngo.org]; \\ ${ }^{2}$ Reptiles \& Amphibiens, UMR 7205 OSEB, Département de Systématique \& Evolution, \\ Muséum national d'Histoire naturelle, 25 rue Cuvier, 75005 Paris, France [bour.roger@gmail.com]; \\ ${ }^{3}$ Ecologia Applicata Italia s.r.l., Rome, Italy [fapetrozzi@gmail.com]; \\ ${ }^{4}$ Department of Applied and Environmental Biology, Rivers State University of Science and Technology, \\ Port Harcourt, Nigeria [gakanina2000@yahoo.com]; \\ ${ }^{5}$ Département de Zoologie et Biologie Animale, Faculté des Sciences, Université de Lomé, \\ BP 1515,LLomé,Togo [h_segniagbeto@yahoo.fr]
}

Summary. - The West African Black Mud Turtle, Pelusios niger (Family Pelomedusidae), is a freshwater turtle of medium size (carapace length to $35.5 \mathrm{~cm}$ ) endemic to permanent wetlands in forested areas of West Africa, and is recognizable within the genus by its hooked maxillary beak. A median keel on the posterior vertebral scutes persists throughout life. The wide, blackish plastron is either uniformly dark or bears a lighter streak along the midline seam. Its field ecology has been studied extensively and quantitatively only in southern Nigeria, with home range, habitat selection, and food habits having been analyzed. The species is omnivorous (but predominantly carnivorous), with dietary composition shifting by season and by site, and also in relation to the extent of pollution of its habitat. Adult sex-ratio is even (1:1). Pelusios niger may potentially be a competitor of $P$. castaneus in forest water bodies of southern Nigeria, and especially in oil-polluted areas, due to an increased niche similarity between these species along the spatial and food niche axes. The species is locally abundant (especially in Nigeria and in Gabon), and its populations appear to be relatively stable. Nonetheless, its main habitats (i.e., forest streams and rivers inside the continuous forest zone) are under threat, and loss of habitat may cause a decline of the populations of this species in the years to come.

Distribution. - Benin, Cameroon, Equatorial Guinea, Gabon, Nigeria, Togo (?). The species has a coastal range in eastern West Africa from Benin (and possibly Togo) to Gabon.

Synonymy. - Sternotherus niger Duméril and Bibron 1835, Sternothaerus niger, Sternothaerus (Anota) niger, Pelusios niger, Sternothaerus oxyrhinus Boulenger 1897, Sternothaerus heinrothi Kanberg 1924.

SubSPECIES. - None recognized at present.

STATUS. - IUCN 2018 Red List Status: Least Concern (LC, assessed 1996, not listed); TFTSG Draft Red List: Near Threatened (NT, assessed 2013); CITES: Not listed.

Taxonomy. - This species was described and illustrated by Duméril and Bibron (1835) as Sternotherus niger, on the basis of a specimen of unknown origin in the Museum national d'Histoire Naturelle (Paris). It was re-described by Boulenger (1897) as Sternothaerus oxyrhinus. It was correctly identified and described by Chabanaud (1934) as Pelusios niger, but was confused with Pelusios subniger, from East Africa, by Loveridge (1941). It was definitively revalidated by Muller and Hellmich (1954).

On the still imprecise western limit of the range, possibly in Nigeria or Togo (see below), there are some specimens which, at least during the juvenile stage, exhibit a pattern and color distinct from normal $P$. niger. In these specimens, the carapace has a light rufous brown to beige background, with a wide median dorsal stripe, and more or less numerous radiating black lines (Bour and Maran 2003). This striking ornamentation appears to fade away when shell length reaches 12 to $15 \mathrm{~cm}$. This distinct morphology has not yet been studied from a taxonomic point of view, but may be significant.

According to Fritz et al. (2011), who studied both mitochondrial and nuclear DNA, $P$. cupulatta is the closest extant sibling species to $P$. niger, as was already noted by Bour and Maran (2003) based on morphological characters in the original description. However, the relationship of this clade with other Pelusios species is unclear, although a possible affinity with $P$. nanus is weakly supported. The karyotype of $P$. niger is $2 \mathrm{n}=34$ (Bull and Legler 1980). 


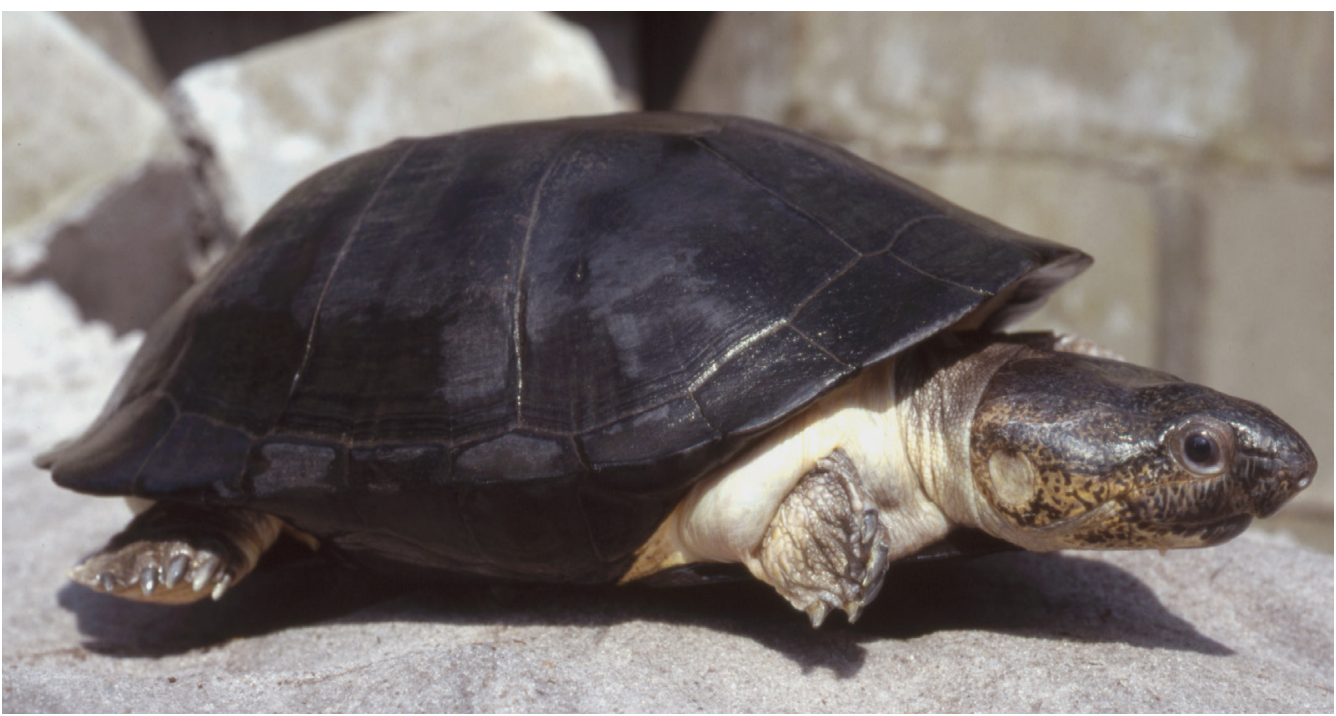

Figure 1. Pelusios niger, adult male, from Gamba, Gabon. Photo by J. Maran.

Description. - This is a medium-sized freshwater turtle; the carapace length (CL) of males may reach 30.0 $\mathrm{cm}$, an exceptional male of $34.8 \mathrm{~cm}$ having increased to $35.5 \mathrm{~cm}$ in captivity. Females are smaller, with a greatest measured CL of $26.5 \mathrm{~cm}$ (Bour and Maran, 2003; Maran and Pauwels, 2005). The carapace is relatively deep, the depth being greater than half the width. The carapacial outline is wide and smoothly elliptical, with slightly elevated lateral borders. The carapace is keeled in juveniles, and persists at least on vertebrals 4 and 5 in the oldest individuals, forming tuberosities. The first marginal scutes are proportionately enlarged (wide and long), and vertebrals $2-4$ become longer than wide at a CL of approximately $20 \mathrm{~cm}$.

The plastron is very large. The intergular scute is both long and wide (Laurent 1965), pentagonal in form, and with an unconstricted anterior margin. The very large abdominal scutes virtually exclude the pectorals from any contact with the marginal scutes. The femorals and anal scutes are equally developed. There is no significant femoro-anal constriction, and the anal notch is obtuse and moderately shallow.

The head is wide to very wide (up to $8.4 \mathrm{~cm}$ wide), and pointed, and the parietal scales are either very short

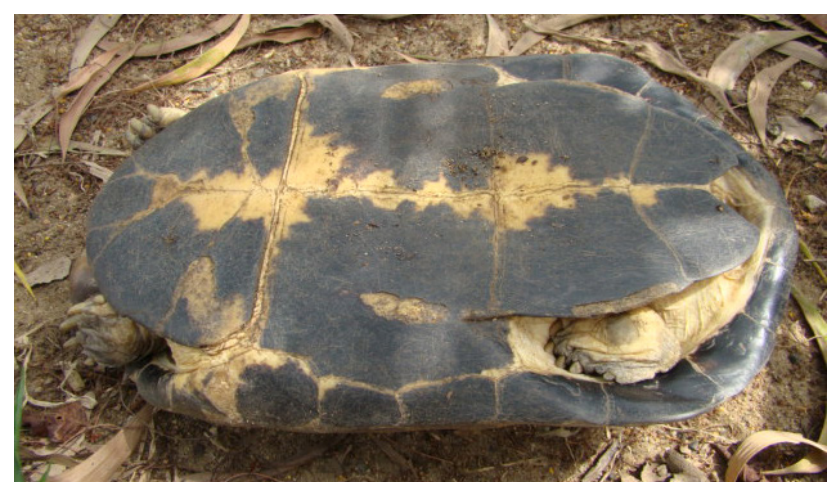

Figure 2. Adult Pelusios niger from Port Harcourt, Nigeria. Photo by L. Luiselli. or absent. The frontoparietal scale is more or less broken up by irregular secondary divisions, and a supralabial is present between the postocular and the masseteric scales. The mental scales (anterior to the barbels) are very narrow or absent. The maxillary beak is anteriorly developed into a very characteristic median hook, a character shared only with $P$. cupulatta. The anterior surface of the forelimb is covered with large rectangular or polygonal scales, not sickle-shaped.
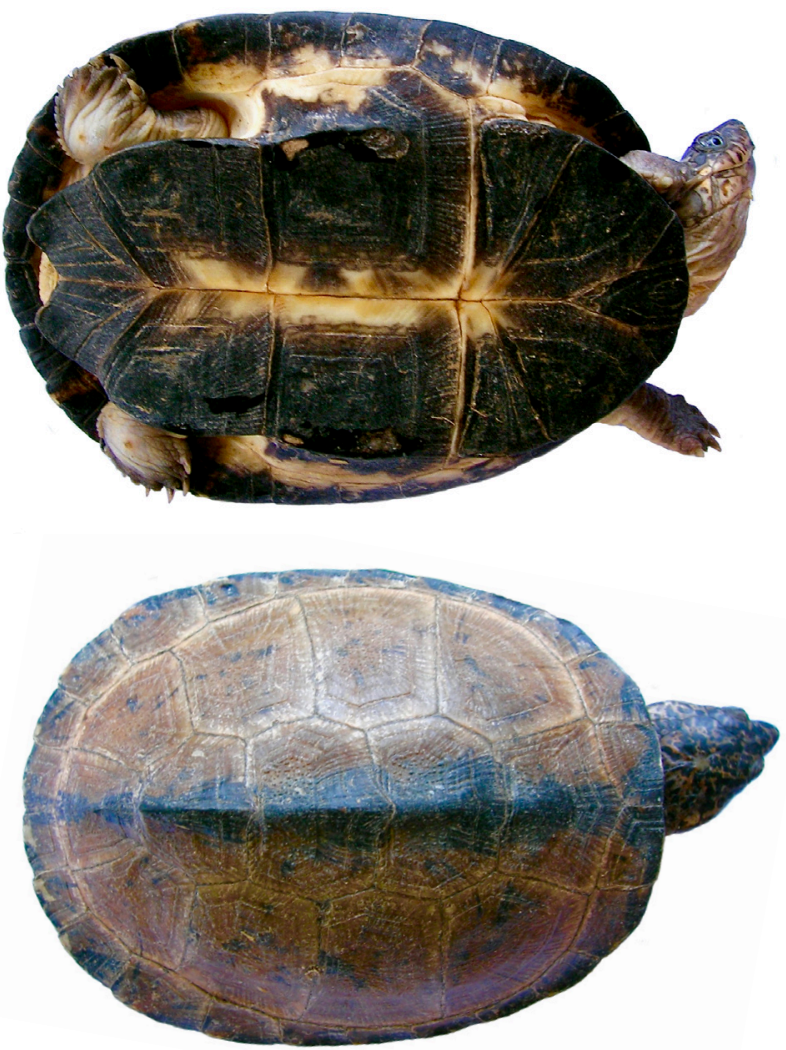

Figure 3. Subadult Pelusios niger from Akwa Ibom State, Nigeria. Photos by T. Diagne. 
The neural series of P.niger is incomplete, usually with 6 to 8 elements, reduced anteriorly and sometimes posteriorly (Broadley 1983). The mesoplastra are very long, their borders almost parallel, and their median suture contained only 1 to 1.5 times in the suture between the hyoplastra.Plastral kinesis in the species was described by Bramble and Hutchison (1981).

The carapace is light brown or olive, to dark brown or black, and darkening with age. The keel is marked with an unbroken dark line. The plastron is uniformly black, or lighter washed-out brown along the midline. Juveniles have characteristic dark triangular markings on the undersides of the marginal scutes. The soft parts are dark gray or brown, becoming grayish or light brown beneath the carapace. The top and sides of the head, up to the rhamphothecae, are light brown with black dots; with age, they form a pattern of narrow streaks, vermiculations, or light marbling on a dark background.

Distribution. - Pelusios niger is endemic to the eastern coastal nations of the Gulf of Guinea, including Togo (possibly), Benin, southern Nigeria, western Cameroon, Equatorial Guinea, and western Gabon. The locality "Tschadsee" (Lake Chad) (based on ZMB 27269) cited by Fritz et al. (1993) is

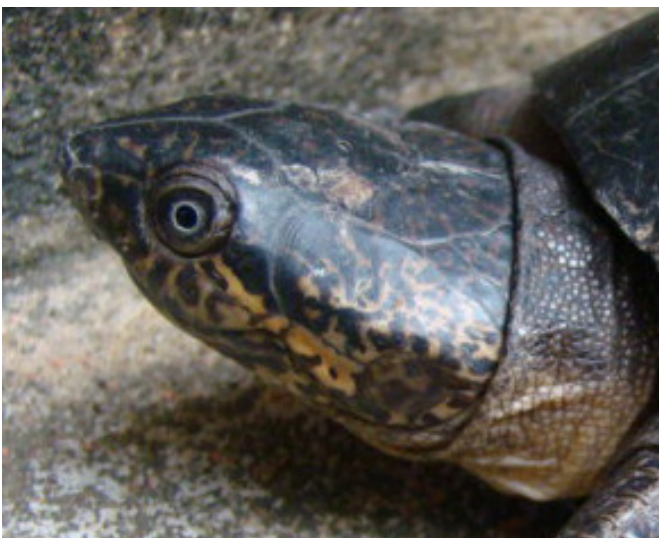

Figure 4. Subadult Pelusios niger from Itu, Nigeria. Photo by L. Luiselli.

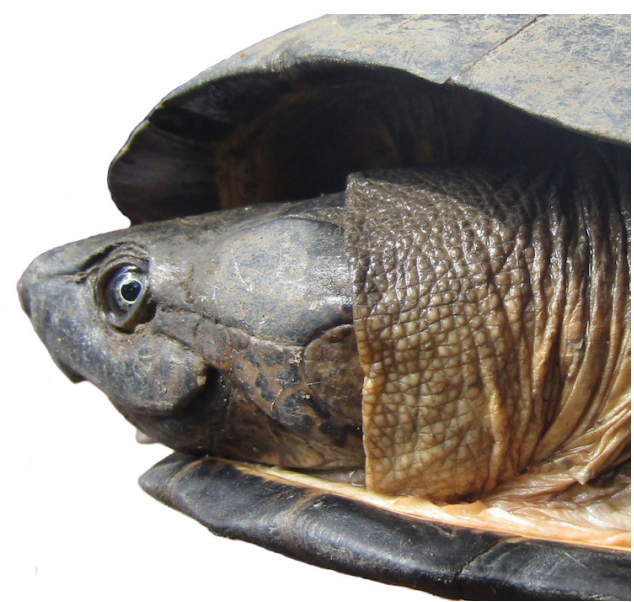

Figure 5. Large adult male Pelusios niger from Calabar, Cross River State, Nigeria. Photo by L. Luiselli. incorrect, as that specimen is actually $P$. cupulatta, a species which is absent from this region (Bour and Maran 2003).

The presence of $P$. niger in Togo needs additional confirmation. In a checklist of Togolese chelonians, Matschie (1893) mentioned Sternothaerus niger, adding a rather ambiguous remark: "Noch nicht von Togo nachgewiesen" ["not yet confirmed from Togo"], which is in disagreement with another of Matschie's comments: "Wenn kein Fundort angegeben wird, so bedeutet dieses, dass die betreffende Art für Togo bereits nachgewiesen ist." ["When no locality is indicated, that means that the species has already been confirmed from Togo."']. It is unclear if the species was not recorded from Togo prior to Matschie, or still unknown at the time of his publication. In any case, Pelusios niger has now been recorded from one locality in Togo, the area of Lama Kara, Kara (ca. $9^{\circ} 30^{\prime} \mathrm{N}, 1^{\circ} 10^{\prime}$ E), with a deposited voucher in the Zoologisches Museum Hamburg (ZMH R03862) (Segniagbeto et al. 2014). The habitat of this site is, however, very different from that typically occupied by the species (much drier, being dry savannah instead of forest), and hence we suggest that further records are needed before confirming the native occurrence of $P$. niger in Togo (Segniagbeto et al. 2014). Another specimen originally identified as P. niger, allegedly originating from Togo (MNHN 2000.2614) is instead a specimen of $P$. cupulatta (Bour and Maran 2003).

In Nigeria, $P$. niger is widespread and locally very abundant in the southern regions, inside the continuous rainforest vegetation zone, where it inhabits rivers, creeks, and permanent ponds surrounded by swamp forest and gallery forest (Akani et al. 1999; Luiselli et al. 2000; Lea et al. 2003). In the Niger Delta it is still common in most of the perennial water bodies (Luiselli and Politano 1999; Akani et al. 2015a) despite heavy hunting with fishing traps (Akani et al. 2015b), and in the Cross River basin it is certainly the commonest of all turtle species (Luiselli and Politano 1999).
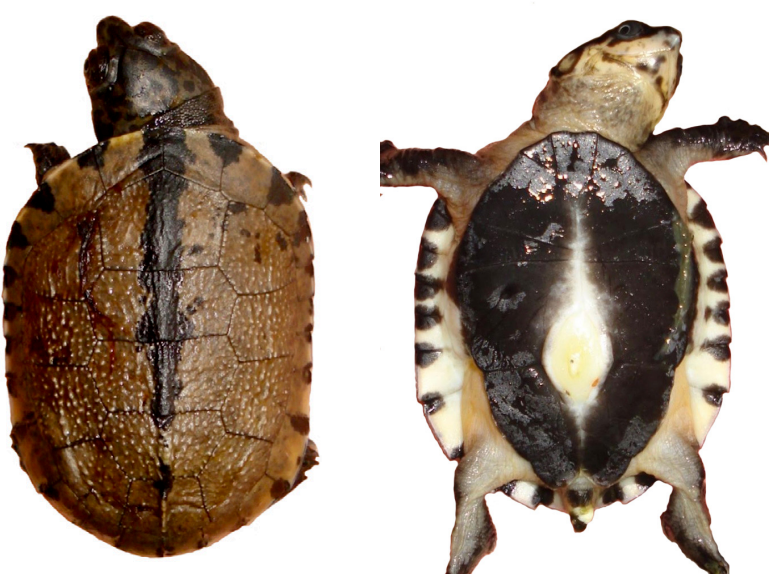

Figure 6. Hatchling Pelusios niger from nr. Lagos, Nigeria, with light carapacial coloration. Photos by F. Grünewald. 


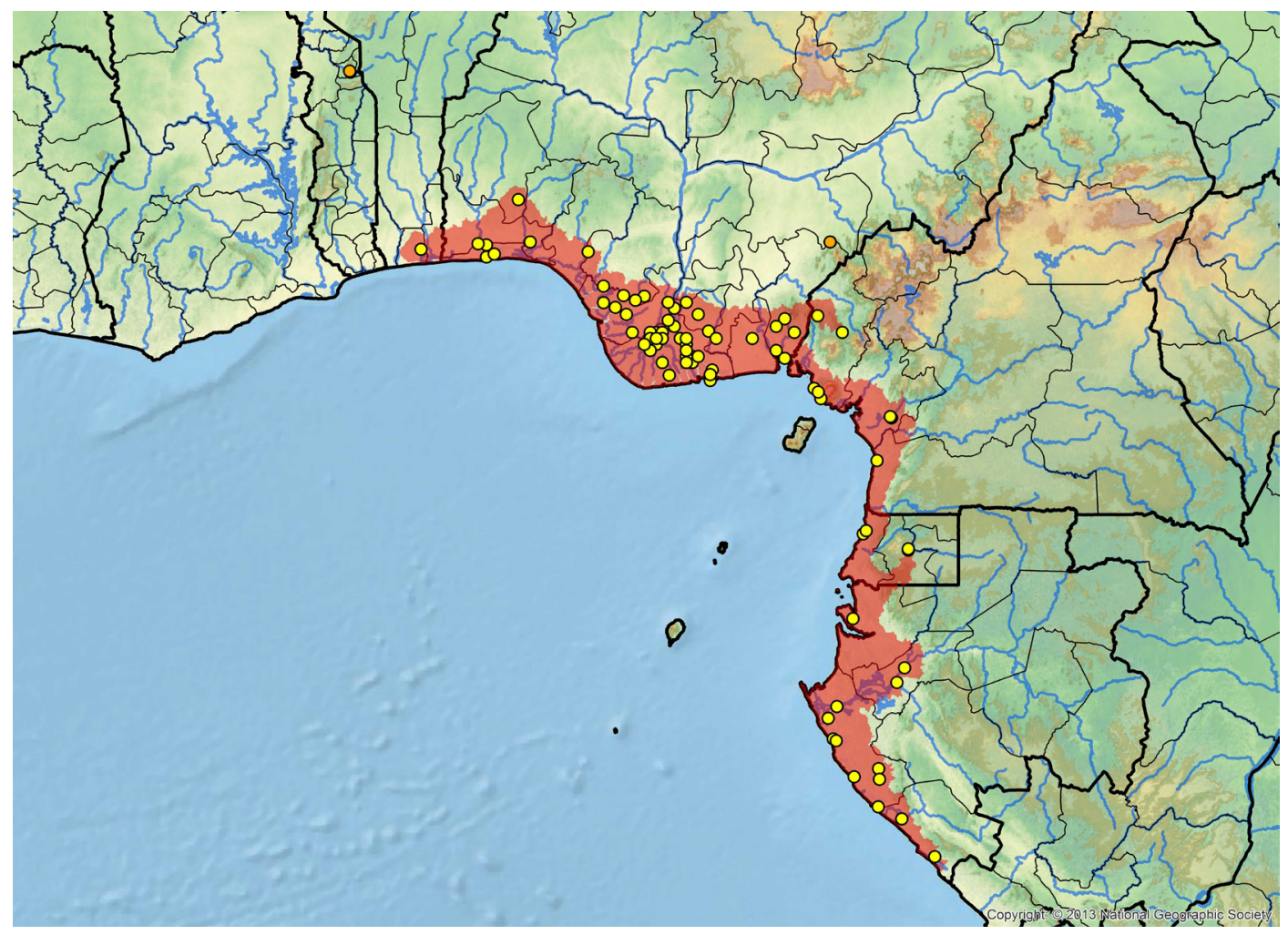

Figure 7. Historic distribution of Pelusios niger in western and central Africa. Yellow dots $=$ museum and literature occurrence records of native populations based on Iverson (1992) plus more recent and authors' data; orange dots = uncertain native or trade or introduced specimens; red shading = projected historic distribution. Distribution based on GIS-defined level 10 HUCs (hydrologic unit compartments) constructed around verified localities and then adding HUCs that connect known point localities in the same watershed or physiographic region, and similar habitats and elevations as verified HUCs (Buhlmann et al. 2009; TTWG 2017), and adjusted based on authors' subsequent data.

In Cameroon it is found in the forest water bodies of the southwestern regions (Lawson 1993; Chirio and LeBreton 2007), but absent from most of the country (Chirio and LeBreton 2007).

In Gabon it is also mainly restricted to the littoral region, in the provinces of Estuaire, Ogooué-Maritime, Nyanga, and Moyen-Ogooué. Like P. castaneus, $P$. niger reaches Lambaréné in Moyen-Ogooué thanks to the large marshy plains bordering the Ogooué River (Maran and Pauwels 2005).

Habitat and Ecology. - Although most of the observations on habitat use by P. niger are anecdotal and/ or descriptive without robust statistical design, it is clear that its ecological distribution corresponds roughly to the limits of closed forest (Branch 2007). Nonetheless, P. niger is not necessarily linked to the permanent water bodies found inside forest blocks, but also occurs in fully exposed bodies of water, including mangrove creeks, where it often co-occurs with P. castaneus (Akani et al. 1999; Luiselli et al. 2000; Maran and Pauwels 2005). Overall, at least in southern Nigeria, the habitat type where it can reach the highest population densities is that of medium to large rivers crossing through rainforest or areas with gallery forest on the banks. In Gabon, its presence is often associated with clumps of Cyperus (Cyperaceae) bordering lakes and rivers, sometimes making large and impenetrable areas. Although notably found in open aquatic environments, it is also found sporadically in shallow wetlands (Maran and Pauwels 2005).

The only quantitative analyses of habitat use by P.niger came from Nigerian populations (Luiselli et al. 2000). In the Niger Delta of southern Nigeria, the presence of this species has been found to be positively correlated to the presence of mature dry forest on the banks and especially of mature swamp/flooded forest on the banks, whereas this latter habitat type did not positively influence the probability of presence of the coexisting P. castaneus.

The habitat use by P.niger in the Niger Delta of southern Nigeria also depended considerably on the pollution level of the water bodies; in relatively unpolluted areas, it mainly inhabited main river tracts and forest ponds (Luiselli and Akani 2003). In areas polluted by oil spills, its habitat selection shifted markedly, with most of the remaining individuals concentrated along the main river tract and nearly disappearing from forest ponds (Luiselli and Akani 2003). In addition, the spatial niche breadth tended to be significantly narrower in oil-polluted areas than in unpolluted biotopes (Luiselli and Akani 2003), and the population numbers also declined considerably after oil spills (Luiselli et al. 2006a).

Pelusios niger occurs from sea level (for instance, in the coastal forests of the River Niger Delta in southern Nigeria; 
Luiselli et al. 2000) up to at least 600 m elevation in Cross River National Park, Nigeria.

The species is considered to be omnivorous, but mainly carnivorous (Ernst and Barbour 1989; Luiselli et al. 2004; Akani et al. 2015c), with the quantitative aspects of its diet known only from some populations of the forest streams of the Niger Delta in southern Nigeria. In a riverine area of the eastern Niger Delta, the taxonomic composition of the diet of $P$. niger consisted mainly of fish, annelids, and gastropods, and secondarily of anurans and plant matter (Luiselli et al. 2004). At another site along the Forcados River, food items found inside the stomachs of dissected turtles included snails (13 of 32 analyzed stomachs), insects (22 of 32 stomachs), fish (21), oil palm fruits (4), and pawpaw and banana (3 respectively) (Akani et al. 2015c). In the same region, the diet of this turtle varies significantly also by season, with fruits and crustaceans consumed more in the dry season, and amphibian eggs and tadpoles more in the wet season (Luiselli et al.2004). However, in Gabon, aquatic plants are prominent in the diet of the species (Maran and Pauwels (2005). In shallow wetlands, it is often observed feeding on the invasive water hyacinth (Eichhornia crassipes, Pontederiaceae).

The species has been considered to be normally crepuscular or nocturnal (Ernst and Barbour 1989), although it is occasionally seen basking on floating logs (Maran and Pauwels 2005), and individuals can be easily captured during the daytime in Nigeria (Luiselli et al., unpubl. data).

Data available on the reproductive biology of $P$. niger in the field are scarce. The autopsy of a female of $22 \mathrm{~cm} \mathrm{CL}$ revealed the presence of 10 large oblong pale pinkish eggs. The eggs measured 47-49 $\mathrm{mm}$ long and 24-25 mm wide, with a mass of 17-18 g each (Maran and Pauwels 2005). In the Niger Delta of southern Nigeria, the number of eggs ranged from 18-28 with an average of $25 \pm 2(n=15)$, and measured 30-40 mm in length (mean, 35.5 $\pm 4 \mathrm{~mm}$ ) (Akani et al. 2015c). Nesting sites were frequently found in muddy burrows at the shoreline. Hunters report that every year, by flood season, people who know how to identify the nests come along the shore to search for and collect both adults and eggs in the nest (Akani et al. 2015c).

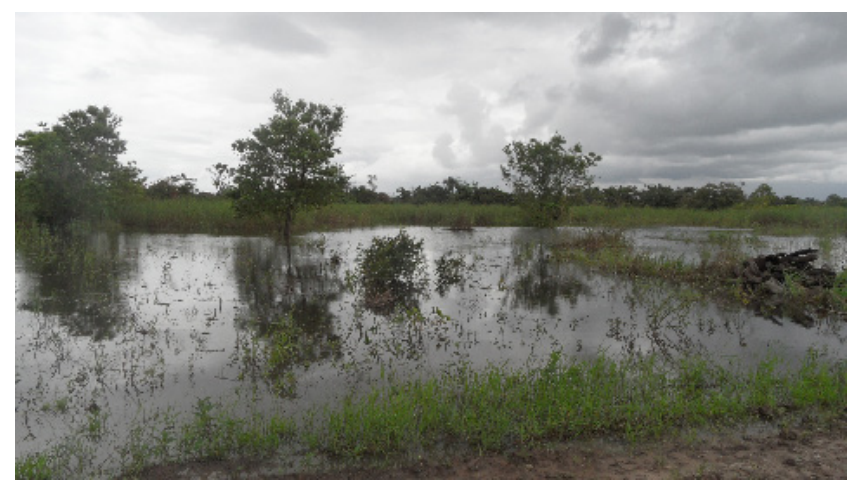

Selection of nesting sites has been studied by radiotracking 10 gravid females in the Niger Delta of southern Nigeria ( 6 from a pristine forest stream and 4 from an oil-polluted area; Luiselli et al.2006b). There was a clear preference for nesting sites situated along ponds and not along the banks of the river, typically with abundant vegetation and sandy soil, at both pristine and polluted sites. In addition, there was a tendency to nest at greater distances from the water in the polluted study area than in the pristine study area (Luiselli et al. 2006b). Most of the females oviposited at less than $20 \mathrm{~m}$ from the water bodies at an unpolluted site, but at more than $50 \mathrm{~m}$ at an oil-polluted site (Luiselli et al. 2006b).

Home ranges were studied by radiotracking 38 individuals for over 60 days each, at two study areas in the Niger Delta of southern Nigeria (Luiselli et al. 2006b). In an unpolluted forest stream, adult females had a mean home range of $2.0 \pm 0.6$ ha, and males of $2.5 \pm 0.6$ ha, with no statistically significant differences (Luiselli et al. 2006b). However, the mean home ranges were significantly larger in an oil-polluted site in the same geographic area, for both females $(5.0 \pm 1.5 \mathrm{ha})$ and males $(5.2 \pm 0.9 \mathrm{ha})$, probably because the turtles needed more extensive movements to find suitable habitats to survive (Luiselli et al. 2006b).

Adult sex ratio (males: females) was close to $1: 1$ in the wild populations studied in the Niger Delta of Nigeria (Akani et al. 2015c). Density in the field has not been well studied: Lameed and Ayodele (2010) reported a density of 0.9 individuals per km of river in Ogun State, western Nigeria, but their visual surveys certainly underestimated the real local population density of these elusive turtles.

Pelusios niger may potentially be a competitor of $P$. castane us in the forest water bodies of southern Nigeria, given that they exhibit relatively similar habitat choices and dietary habits (Luiselli et al. 2004). The intensity of interspecific competition between these turtle species appears intensified in oil-polluted sites, due to a higher similarity in space use and food items (Luiselli and Akani 2003; Luiselli et al. 2004). Indeed, sophisticated statistical simulations (Monte Carlo permutations on dedicated null model algorithms)

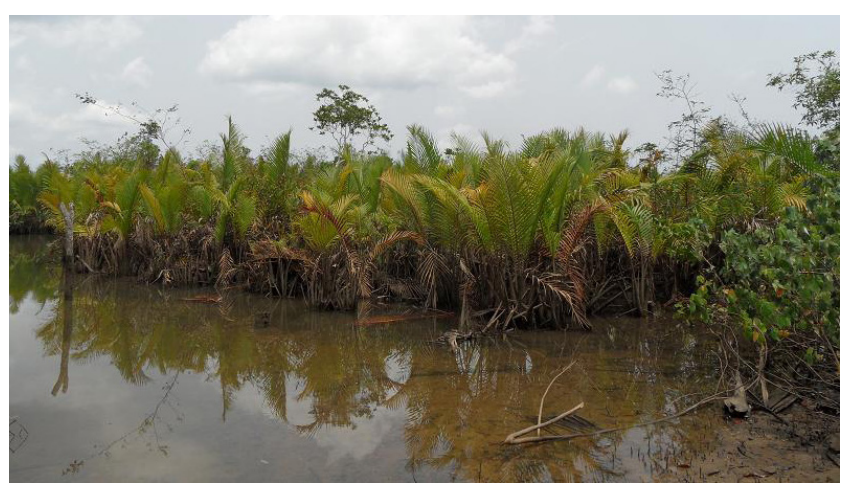

Figure 8. Riverine habitats of Pelusios niger along the Nun River course (left), and the Forcados River course (right), in the Niger Delta region of southern Nigeria. Photos by G.C. Akani. 
revealed there was a statistically significant increase in the similarity of habitat use in polluted areas between these two Pelusios species, with increased potential for interspecific competition (Luiselli et al. 2006a,b). However, the different body sizes of these turtles (P. niger is a larger species) may possibly minimize the intensity of interspecific competition between them through differential use of differently sized food resources (Luiselli et al. 2004). Although P. niger is equipped with an impressively hooked maxillary beak, it does not appear to be especially aggressive.

Many wild individuals are externally parasitized by leeches in Nigeria and Gabon (Maran and Pauwels 2005; Luiselli et al., unpubl. data), and they frequently expel intestinal worms.

Population Status. - Pelusios niger is a species of limited distribution, poorly represented in museum collections, although sometimes reaching high local abundance, as in the swamps and coastal streams of Gabon and Nigeria.Local declines may have occurred at a few study sites in the Niger Delta of southern Nigeria. For instance, the species tends to be quickly extirpated from sites subjected to oil spillages (Luiselli and Akani 2003; Luiselli et al. 2006a). Interestingly, however, in the year 2002 it was observed in the Ethiope River, Delta State of Nigeria, where it had not been found in 1982, despite considerable human development and deforestation that had occurred (Lea et al. 2003).

Overall, there is no evidence that population declines are in any way generalized, although no long-term monitoring data on any natural populations are available and the species is heavily hunted (with fishing traps) in several sites (Akani et al.2015b). However, its natural habitat (permanent water bodies within the forest block of eastern West Africa) tend to be under severe threat due to industrial expansion and deforestation (Akani et al. 1999; Luiselli et al. 2000), and its overall range is fairly small.

Threats to Survival. - Pelusios niger is widespread in eastern West Africa and locally abundant in several places in its range, but is regularly collected by humans for food (e.g., Branch 2007; Luiselli et al. 2013; Akani et al. 2015). In Gabon, because of its large size, the species is particularly sought after for local consumption, especially in the lakes around Lambaréné (Gramentz 1999; Maran and Pauwels 2005). Its flesh and eggs are greatly appreciated. Pelusios niger is caught by fishing or more occasionally with a trammel. In the dry season, turtles inhabiting swamps hide in tangles of aquatic plants. Using a machete or a simple piece of sharpened wood, hunters probe these areas and are able to capture a large number of turtles.

Locally, the species is affected by pollution and degradation of its primary habitats. In the Niger Delta of Nigeria, for instance, several populations are collapsing due to the effects of oil spill contaminations (Luiselli and Akani 2003; Luiselli et al. 2004, 2006a,b; Luiselli 2008).

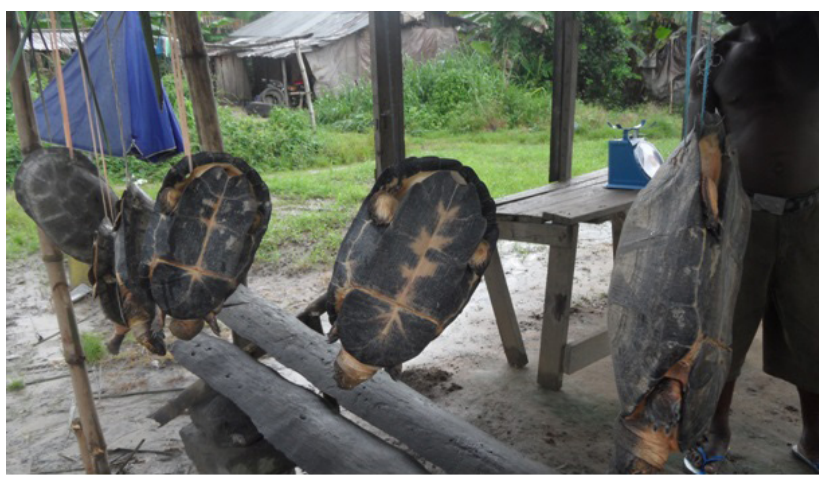

Figure 9. Specimens of Pelusios niger displayed for sale at Aven bushmeat market, Patani Local Government area, Niger Delta, Nigeria. Photo by G.C. Akani.

Pelusios niger is often exported from Africa for sale to turtle hobbyists, with Ghana and Benin being the main exporting countries (Ineich 2006; Segniagbeto 2009). However, there is no evidence that the international pet trade is currently threatening wild populations of this species.

Conservation Measures Taken. - At the present time, P. niger is not the focus of any directed conservation effort, although it occurs within several protected areas within its range. Among the protected areas where this species occurs, it has been recorded in Okomu National Park, Upper Orashi Forest Reserve (Akani et al. 2015a), Taylor Creek Forest Reserve (Akani et al. 2014), Stubbs Creek Forest Reserve (Singh et al. 1995), and Cross River National Park (Reid 1989) in Nigeria and the Korup National Park in Cameroon (Lawson 1993). In Gabon, it has so far been recorded only from Loango National Park (Maran 2002), but might also be expected to occur in Akanda,Mayumba,Moukalaba-Doudou, and Pongara National Parks, all also situated in the coastal plains (Pauwels and Maran 2007).

Pelusios niger was assessed for the IUCN Red List as Least Concern in 1996 by the IUCN Tortoise and Freshwater Turtle Specialist Group (TTWG 2017), and therefore not formally listed at that time. It was subsequently assessed as Near Threatened at the IUCN Red Listing workshop on African chelonians in Lomé, Togo, in August 2013 (TTWG 2017).

Conservation Measures Proposed. - Given that the main threats are local (bushmeat) consumption and habitat loss, monitoring of trends in bushmeat markets (numbers offered, average size of animals traded) and population monitoring at a few key protected areas would be justified. Also, more conservation biology research would be desirable, including data on hatchling size, incubation time, age and size at maturity, longevity, annual reproductive output, etc. Export quantities for the international pet trade should also be continuously monitored in order to mitigate the potential adverse effects of the trade on wild population sizes and to adjust export quotas as necessary. Populations in areas affected by oil pollution should also be monitored. 
Captive Husbandry. - This species does well in captivity, where it can be kept at $27-31^{\circ} \mathrm{C}$ water temperature and $28-32^{\circ} \mathrm{C}$ air temperature. In captivity it feeds almost exclusively on animal food, including fish, crustaceans, insects, mollusks, and meat, but accepts pet pellets and also tender fruits like pears. In captivity, P. niger is much more sensitive to polluted water than $P$. castaneus, with bacterial diseases quickly appearing on its skin and scutes when the water of its tank is not clean. Like other species of this family, when molested, P. niger secretes an oily odoriforous yellowish liquid from axillary and inguinal glands. Despite its large head, powerful jaws and strong hooked beak, this species ordinarily does not try to bite.

Current Research. - Currently, P. niger is not the subject of any specifically dedicated ecology research projects. However, it is one of several target turtle and tortoise species of an ongoing long-term mark-recapture research project in southern Nigeria. This long term project has been carried out for more than 15 years under the supervision of Luiselli and in collaboration with scientists at the Rivers State University of Science and Technology (mainly Godfrey C. Akani) and at the University of Uyo (mainly Edem A.Eniang). The Nigerian studies also involve monitoring of bushmeat markets in order to verify whether trade trends vary over the years (Luiselli et al.2013). Luiselli, Fabio Petrozzi, and Godfrey C. Akani are studying the ethnozoology of these turtles in Nigeria. Taxonomic research should be considered to study the identity of the western specimens of $P$. niger exhibiting a carapacial radiating pattern (see above) and the relationships with the species $P$. cupulatta.

Acknowledgments. - Luiselli acknowledges Edem A. Eniang and Edoardo Politano for many years of field cooperation, mainly in Nigeria and Togo. Luiselli's research on African turtles was supported over the years by Eni s.p.a., Agip (Nigerian Agip Oil Company), Aquater s.p.a., Snamprogetti s.p.a., Chelonian Research Foundation, the Mohamed bin Zayed Species Conservation Fund, and Turtle Conservation Fund via Conservation International. We thank Olivier Pauwels for additional information on the distribution of the species, and Jérôme Maran, Ferry Grünewald, and Tomas Diagne for their photos.

\section{LITERATURE CITED}

Akani, G.C., Luiselli, L., And Politano, E. 1999. Ecological and conservation considerations on the reptile fauna of the eastern Niger Delta (Nigeria). Herpetozoa 11:141-153.

Akani, G.C., Aifesehi, P.E.E.,Petrozzi , F., Amadi, N., And Luiselli, L. 2014. Diversity of terrestrial vertebrates in Taylor Creek Forest Reserve, an area of high environmental value in the River Niger Delta (Bayelsa State, Nigeria). Vie et Milieu - Life and Environment 64:59-68.

Akani, G.C., Aifesehi, P.E.E., Petrozzi , F., And Luiselli, L. 2015a. Aspects of community ecology of reptiles in the swamp forests of the Upper Orashi Forest Reserve (Niger Delta, Nigeria). African Journal of Ecology, doi: 10.1111/aje.12176.

Akani, G.C., Petrozzi, F., Ebere, N., Dendi, D., Phil-Eze, P., Amadi, N., AND LuISELli, L. 2015b. Correlates of indigenous hunting techniques with wildlife trade in bushmeat markets of the Niger Delta (Nigeria). Vie et Milieu - Life and Environment 65:169-174.

Akani, G.C.,Petrozzi, F., Segniagbeto, G.H. and Luiselli, L. 2015c. Notes on morphology, biology and domestic consumption of Pelusios niger (Duméril \& Bibron, 1835) from Forcados River, Nigeria. Herpetozoa 12:94-98.

Bour, R. and Maran, J. 2003. Une nouvelle espèce de Pelusios de Côte d'Ivoire (Reptilia, Chelonii, Pelomedusidae). Manouria 6 (21): 24-43.

BRAmble, D.M. ANd Hutchison, J.H. 1981. A reevaluation of plastral kinesis in African turtles of the genus Pelusios. Herpetologica 37(4):205-212.

BRANCH, B. 2007. Tortoises, Terrapins and Turtles of Africa. Struik Publishers, Cape Town.

BRoAdley, D.G. 1983. Neural pattern - a neglected taxonomic character in the genus Pelusios Wagler (Pleurodira: Pelomedusidae). In: Rhodin, A.G.J. and Miyata, K. (Eds.). Advances in Herpetology and Evolutionary Biology: Essays in Honor of Ernest E. Williams. Cambridge: Museum of Comparative Zoology, pp. 159-168.

Buhlmann, K.A., Akre, T.S.B., Iverson, J.B., Karapatakis, D., Mittermeier,R.A., GeOrges,A.,Rhodin,A.G.J., vAN DiJK,P.P., AND GibBons, J.W. 2009. A global analysis of tortoise and freshwater turtle distributions with identification of priority conservation areas. Chelonian Conservation and Biology 8:116-149.

BULL, J.J. AND LEGLER, J.M. 1980. Karyotypes of side-necked turtles (Testudines:Pleurodira).Canadian Journal of Zoology 58:828-841.

Chirio, L. And Lebreton, M. 2007. Atlas des Reptiles du Cameroun. Publ. Sc. MNHN, IRD éd., Paris, 688 pp.

ERnst, C.H. AND BARBour, R.W. 1989. Turtles of the World. Washington DC: Smithsonian Institution Press, $312 \mathrm{pp}$.

FRITZ, U., OBSt, F.J. AND GÜNTHER, R. 1993. Kritischer Typenkatalog derSchildkrötensammlung(Reptilia:Testudines)des Zoologischen Museums Berlin. Mitteilungen aus dem Museum fürNaturkundein Berlin. Zoologisches Museum und Institut für Spezielle Zoologie (Berlin) 70: 157-175.

Fritz, U., Branch, W.R., Hofmeyr, M.D., Maran, J., Prokop, H., Schleicher, A., ŠIrokÝ, P., Stuckas, H., Vargas-Ramírez, M., Vences M., AND HundSDÖRFER, A.K. 2011. Molecular phylogeny of African hinged and helmeted terrapins (Testudines: Pelomedusidae: Pelusios and Pelomedusa).Zoologica Scripta 40:115-125.

Gramentz, D. 1999.Zur Oekologie und zum Verhalten von Pelusios castaneus (Schweigger, 1812) und Pelusios niger (Duméril \& Bibron, 1835) in Gabun. Sauria 21 (3):7-14.

INEICH, I. 2006. Les élevages de reptiles et de scorpions au Bénin, Togo et Ghana - plus particulièrement la gestion des quotas d'exportation et la définition des codes "source" des spécimens exportés. Projet CITES A-251, Berne.

IvERSON, J.B. 1992. A Revised Checklist with Distribution Maps of the Turtles of the World. Richmond, IN: Privately printed, $363 \mathrm{pp}$.

LAMEED, G.A. ANDAYODELE,A.E. 2010.Effect of quarrying activity on biodiversity: Case study of Ogbere site, Ogun State Nigeria.African Journal of Environmental Science and Technology 4: 740-750.

LAURENT, R.F. 1965. A contribution to the knowledge of the genus Pelusios (Wagler).Annales du Musée Royaldel'Afrique Centrale, Sciences Zoologiques, Tervuren 135:1-33.

Lawson, D.P. 1993. The reptiles and amphibians of the Korup National Park Project, Cameroon. Herpetological Natural History 1(2):27-90. 
Lea, J.R., Politano, E., and Luiseldi, L. 2003. Changes in the herpetofauna of a fresh water river in Southern Nigeria, after 20 years of development.Russian Journal of Herpetology 10:191-198.

Luisell, L. 2008. Linnaeus Fund research report: assessing the home range and oviposition site selection in freshwater turtles from pristine and oil-polluted habitats in the Niger Delta, Nigeria. Turtle and Tortoise Newsletter 12:18-20.

Luiselli, L. AND AKani, G.C. 2003. An indirect assessment of the effects of oil pollution on the diversity and functioning of turtle communities in the Niger Delta, Nigeria.Animal Biodiversity and Conservation 26.1:57-65.

Luiselli, L. ANd Politano, E. 1999. An update of distribution, status, and habitats of crocodiles and chelonians in the eastern Niger Delta (Port Harcourt region of Nigeria), with a planning for conservation and management. Report to AGIP Environmental Department, Milano.

Luiselli, L., Politano, E., And Angelici, F.M. 2000. Ecological correlates of the distribution of terrestrial and freshwater chelonians in the Niger Delta, Nigeria: a biodiversity assessment with conservation implications. Revue d'Ecologie (Terre et Vie) 55:3-23.

Luiselli, L., Akani, G.C., Politano, E., Odegbune, E., and Bello, O. 2004. Dietary shifts of sympatric freshwater turtles in pristine and oil-polluted habitats of the Niger Delta, Southern Nigeria. Herpetological Journal 14:57-64.

Luiselli, L., AKani, G.C., AND Politano, E. 2006a. Effects of habitat alteration caused by petrochemical activities and oil spill on the habitat use and interspecific relationships among four species of Afrotropical freshwater turtles. Biodiversity and Conservation 15:3751-3767.

Luiselli, L., Akani, G.C., Bello, O.A., Angelici, F.M., And Ude, L. 2006b. Home range area may vary considerably in relation to habitat contamination in two African terrapins from pristine and oil polluted habitats. Amphibia-Reptilia 27:255-261.

Luiselli, L., Petrozzi, F., And Akani, G.C. 2013. Long-term comparison reveals trends in turtle trade in bushmeat markets of southern Nigeria. Herpetozoa 26: 57-64.

MARAN, J. 2002. Les tortues continentales du Gabon. La Tortue 58-59:46-67.

Maran, J. 2006. Observations on Gabonese chelonians. In: Artner, H., Farkas, B. and Loehr, V. (Eds.). Turtles - Proceedings: International Turtle \& Tortoise Symposium, Vienna 2002, pp. 351-373. Frankfurt-am-Main: Chimaira Editions.

Maran, J. AND Pauwels, O.S.G. 2005. État des connaissances sur les tortues continentales du Gabon: distribution, écologie et conservation. Bulletin de l'Institut Royal des Sciences Naturelles de Belgique, Biologie 75:47-60.
Pauwels, O.S.G. and Maran, J. 2007. Occurrence of tortoises and freshwaterturtles (Pelomedusidae, Testudinidae, and Trionychidae) in the National Parks of Gabon - 2006 status of knowledge. Turtle and Tortoise Newsletter 10:21-26.

Pauwels, O.S.G., Christy, P., AND Honorez, A. 2006. Reptiles and National Parks in Gabon, western Central Africa. Hamadryad 30:181-196.

Pauwels, O.S.G., Burger, M., Branch, W.R., Tobi, E., Yoga, J.-A., and Mikolo, E.N. 2007. Reptiles du Complexe d'Aires Protégées de Gamba, sud-ouest du Gabon. Bulletin of the Biological Society of Washington 12: 91-100.

REID, J.C. 1989. Floral and faunal richness of the Oban Division of Cross River National Park. WWF Feasibility Study, 6th European Development Fund, No. 607.30.94.184. Calabar, Nigeria.

Segniagbeto, G.H. 2009. Herpétofaune du Togo: Taxinomie, Biogéographie. Thèse de doctorat. Univ. Lomé (Togo) \& MNHN Paris (France). Tome I : 1-172 \& Tome II : 1-192.

Segniagbeto, G.H., Bour, R., Ohler, A., Dubois, A., Rödel, M.O., Trape, J.F., Fretey, J., Petrozzi, F., And Luiselli, L. 2014. Turtles and tortoises of Togo: historical data, distribution, ecology and conservation. Chelonian Conservation and Biology 13:152-165.

Singh,J.,MofFAT, D., ANDLinden, O. 1995. Defining an environmental development strategy for the Niger Delta. Industry and Energy Operations Division West Central Africa Department, World Bank, 2 volumes.

TTWG [Turtle Taxonomy Working Group] [Rhodin, A.G.J., Iverson, J.B., Bour, R. Fritz, U., Georges, A., ShafFer, H.B., AND VAN DiJk, P.P.]. 2017. Turtles of the World: Annotated Checklist and Atlas of Taxonomy, Synonymy, Distribution, and Conservation Status (8th Ed.). In: Rhodin, A.G.J., Iverson, J.B., van Dijk, P.P., Saumure, R.A., Buhlmann, K.A., Pritchard, P.C.H., and Mittermeier, R.A. (Eds.). Conservation Biology of Freshwater Turtles and Tortoises: A Compilation Project of the IUCN/SSC Tortoise and Freshwater Turtle Specialist Group. Chelonian Research Monographs 7:1-292.

\section{Citation Format for this Account:}

Luiselli, L., Bour, R., Petrozzi, F., Akani, G.C., and Segniagbeto, G.H. 2018. Pelusios niger (Duméril and Bibron 1835) - West African Black Mud Turtle. In: Rhodin, A.G.J., Iverson, J.B., van Dijk,P.P.,Stanford,C.B.,Goode,E.V.,Buhlmann,K.A.,Pritchard, P.C.H., and Mittermeier, R.A. (Eds.). Conservation Biology of Freshwater Turtles and Tortoises: A Compilation Project of the IUCN/SSC Tortoise and Freshwater Turtle Specialist Group. Chelonian Research Monographs 5(12):105.1-8. doi: 10.3854/ crm.5.105.niger.v1.2018; www.iucn-tftsg.org/cbftt/. 